\title{
Effect of School Management on Students' Perceived Academic Achievement among Seventh-Day Adventist Secondary Schools in North- East Tanzania
}

\author{
Emmanuel Allen Senguo* and Dr. Onesto Ozias llomo \\ University of Arusha, Tanzania \\ *Corresponding Author: allenemmanuel.ea@gmail.com
}

\begin{abstract}
This study investigated the effect of school management on students' perceived academic achievement among Seventh- day Adventist secondary schools in in North-East Tanzania. The study employed survey research design, whereby a self-administered questionnaire was distributed to 311 randomly selected students and their responses were analyzed through the Statistical Package for Social Sciences. The study established that school management was effective in planning, motivating and encouraging students to work hard toward maximized academic achievement. However, the school management was perceived ineffective in accepting ideas from students and involving parents in decision making. Students were satisfied with their academic achievement and believed that their academic competence keeps increasing from day to day but were undecided whether teachers and parents are satisfied with their academic achievement. Finally, students' academic achievement is positively influenced by effective school management. Based on the conclusions, the researchers recommended that, while school management is effective in planning, motivating and encouraging students to work hard toward maximized achievement, the school leaders need to improve on acceptance of constructive ideas from students and involving parents in decision making processes. While students were satisfied with their academic achievement and they were undecided whether teachers and parents are satisfied with their academic achievements, there is a need to enhance the interaction between students and their parents and teachers for them to grasp how parents and teachers perceive their academic achievement. Finally, while students' academic achievement is positively influenced be effective school management, there is need for school leaders to improve their managerial practices which will enhance the level of academic achievement by students in the respective schools.
\end{abstract}

Keywords: Management, school management, academic achievement, Adventist secondary schools.

\section{Introduction}

This paper sought to determine the influence of school management on students' achievement. In broad perspectives, management is portrayed as a formal authority to direct and coordinate others. It is the power to influence others with or without authority (Firmina 2015). Academic achievement, on the other hand, refers to the rate at which educational objectives are being achieved by those within the school system. Therefore, academic achievement may be seen as the extent to which students achieve educational goals and objectives (Owan, et al 2018).
Students' academic achievement can be influenced by numerous factors including personal factors, their interactions with parents, teachers, and administrators and the larger systems that surrounds the student e.g. school districts, neighborhoods, local economy, political policy and multicultural relations (Bertolini and Thorngren 2012). According to Jacobson (2011), school management is not only designed to officially titled positions; instead it must be a collective construct that can be spread among teachers and support staff through the creation of relationships and networks in order to improve learning. In other words, academic outcomes are more likely to improve when teachers are empowered in areas 
which they believe are important through management practices. Even though teacher quality has influence students' motivation and achievement, the quality of school management matters in determining the motivation of teachers and the quality of their teaching, which may subsequently affect students' achievement.

In Tanzania, a study conducted by Jengo (2016) found that students' academic achievement comes when heads of schools conduct internal quality assurance on teaching and learning activities, spend most of their time in school dealing with academic issues, reinforce school rules and regulations, delegate responsibilities and promote collegiality spirit among the teachers.

A number of studies such as Feyisa and Amsale (2016), Jengo (2016), Firmina (2015) and Obama, Eunice and Orodho (2015) indicate that the head of school has contribution toward students' achievement through effective managerial practices. A study conducted by Obama, Eunice and Orodho (2015) in Kenya shows that effective school management has been affected by school management and leadership styles. Therefore, this study sought to establish the effect of school management on students' academic achievement among Adventist Secondary Schools in North-East Tanzania. The study was guided by the following research questions:

1. How effective is the school management in Seventh-day Adventist Secondary Schools in North East Tanzania Conference?

2. What is the perceived level of student's academic achievement among Adventist Secondary Schools in North-East Tanzania?

3. Is there significant relationship between effective school management and students' academic achievement?

\section{Related Literature and Studies}

In this chapter, the researchers present theoretical and empirical literature review. The study discusses about different theoretical arguments based on school management and students' achievement.

This study was guided by Transformational Leadership Theory. According to Amanchukwu, Stanley, and Ololube (2015), Transformational Theories focus on the connections formed between leaders and followers. In these theories, leadership is the process by which a person engages with others and is able to create a connection that result in increased motivation and morality in both followers and the leader. Transformational leadership theories are often compared to charismatic leadership theories in which leaders with certain qualities such as confidence, extroversion and positive values are seen as best able to motivate followers, the teachers in the context of this study.

According to Beck-tauber (2012), transformational leaders are said to exercise multiple roles such as coaching or mentoring, communicating, delegating and developing followers. They also enhance the group cohesiveness and inspire cooperative behavior. The mentioned qualities of transformational leadership can play great deal toward students' academic achievement.

The application of management in the education arena can be termed as Educational Administration which is the process of bringing men and materials together for effective and functional teaching and learning in the schools. The focus of educational administration is the enhancement of teaching and learning activities. Educational management can therefore be considered as the process through which the school administrators arrange and coordinate the resources available for education, for the purpose of achieving system goals which, entail the academic achievement of the students (Amadi, 2008).

School Managers should therefore plan school activities and provides guidelines to the school stakeholders. Planning, a process of setting objectives and determining what should be done to achieve them (Mwangi, 2016), is a decision-making activity through which managers act to ensure the future success and effectiveness of their institutions. Planning helps educational managers to anticipate problems and opportunities and to think forward for the realization of school goals. Therefore, planning is one of the best things educational managers should practice as a way of ensuring that school goals and objectives which include students' academic achievement are realized (Surya 2011).

Recent studies report school management as one of the most significant factors affecting student achievement. They clearly indicate that school management team must have a thorough understanding of their roles as instructional leaders (Wahlstrom, Louis, Leithwood, \& Anderson, 2010). Furthermore, Day, Gu and Sammons (2016) in their 
study on the impact of school management on students' outcomes, argue that school principals have to use different mechanisms to make sure that enhanced students' achievement is realized. Therefore, school managers have a great deal to play toward school success.

\section{Research Methodology}

This section describes the design and method applied in carrying out the study. It includes research design, data collection method, population and sampling procedures and statistical treatment of data.

\section{Research Design}

The study employed both designs survey and correlation research design to examine the effect of school management on students' achievement among Seventh-day Adventist Secondary Schools of North - East Tanzania Conference (NETC). The study is quantitative in nature with this regard; the study employed a questionnaire to gather data from selected respondents.

\section{Population and Sampling}

The study involved a simple random sample of 311 students drawn from the population of 1,397 students within three Seventh-day Adventist Secondary Schools in North-East Tanzania Conference: Suji Secondary School, Parane Secondary School and Chome Secondary School.

\section{Data Collection Procedures}

Data were collected through questionnaire from the aforementioned three schools through questionnaire which aimed to examine the effect of school management on students' academic achievement.

\section{Statistical Treatment of Data}

The data were coded and analyzed with the help of Statistical Package for Social Sciences (SPSS) version 21, using descriptive statistics and Pearson correlations. The study sought to examine the effect of school management on students' academic achievement and was guided by three research questions. The data for the first two research questions were analyzed by descriptive statistics in terms of mean scores, which were interpreted as follows: $4.50-5.0=$ strongly agree, 3.50-4.49 = agree, 2.50-3.49 = neutral, 1.50-2.49 = disagree and 1.001.49 = strongly disagree. The third research question called for testing of a hypothesis and therefore it was analyzed through Pearson product Moment Correlation Coefficient.

\section{Finding and Discussion}

This section presents and discusses the findings regarding the effect of school management on students' academic achievement under three research questions.

Research Question 1: How effective is the school management in Seventh-day Adventist Secondary Schools in North East Tanzania Conference?

Table 1: Effectiveness of School Management

\begin{tabular}{llcc}
\hline SN & Items in the Questionnaire & Mean & Interpretation \\
\hline 1 & School management plans school activities and provides guidelines & 3.88 & Agree \\
2 & School management encourages participation of students in school activities & 3.68 & Agree \\
3 & School management consults students and conducts constructive changes & 2.78 & Neutral \\
4 & My school management motivates students to learn hard & 4.47 & Agree \\
5 & School management firmly ensures that the plans set are executed effectively & 3.02 & Neutral \\
6 & School management instructs students and accepts new ideas from them & 2.30 & Disagree \\
7 & School management involves parents in discussing school matters & 1.68 & Disagree \\
\hline
\end{tabular}

This research question sought to establish the effectiveness of school management among secondary schools in North-East Tanzania. Table 1 presents the responses.

Table 1 presents the perception of students on the effectiveness of the school management. The respondents agreed with three items in questionnaire regarding effectiveness of school environment. Particularly, they agreed that school management plans school activities and provides guidelines, that school management encourages participation of students in school activities and that school management motivates students to learn hard. This suggests that school management was perceived effective in terms of planning, encouraging and motivating. The findings agree with those of Nzoka and Orodho (2014) which established that school managers were effective in using various strategies to improve students' academic performance. According to Igbinoba and Marvelous (2015), management effectiveness is very important in the school system, especially in 
the secondary schools where students expect for great achievement as prepare for higher education.

While the men score to two items was between 2.50 and 3.49, students remained undecided whether school management consults students and conducts constructive changes and whether school management ensures that the plans set are executed effectively. However, students disagreed that school management instructs students and accepts new ideas from them and that school management involves parents in discussing school matters. Therefore, failure to accept new ideas from students and lack of parents' involvement in decision making are some of the weaknesses identified by students in the management of schools under investigation.

Research Question 2: What is the perceived level of student's academic achievement among Adventist Secondary Schools in North-East Tanzania?

This research question sought to test the perception of respondents on students' academic achievement as attributed to the quality of school management practices at North East Tanzania Conference. Table 2 below presents the findings based on the responses students as they were filled in the questionnaires.

Table 2: Perception of Students on their Achievement

\begin{tabular}{llcc}
\hline SN & Items in the Questionnaire & Mean & Interpretation \\
\hline 1 & I am satisfied with my achievement in my annual examinations & 3.68 & Agree \\
2 & I achieve well in my quizzes, tests and assignments & 3.58 & Agree \\
3 & I meet the set average pass mark in my exams & 3.72 & Agree \\
4 & My academic competence keeps increasing from day to day & 3.92 & Agree \\
5 & My academic achievement is better than that of other students in the same level & 3.66 & Agree \\
6 & My teachers and parents are satisfied with my academic achievement & 3.25 & Neutral \\
7 & I am eager to continue with my academic achievement to the next level & 4.78 & Strongly Agree \\
\hline
\end{tabular}

The findings presented in table 2 indicate that students agreed with the first five items and strongly agreed with the last item. Particularly, students agreed that they are satisfied with their academic achievement in annual examinations, they achieve well in their quizzes, tests and assignments, they meet the set average pass marks, their academic competence keeps increasing from day to day, and their teachers and that their academic achievement is better than that of other students in the same level. The also strongly agreed that they are eager to continue with their academic achievement to the next level. It is worth noting that students perceived their academic achievement to be high. However, students were undecided whether teachers and parents are satisfied with their academic achievement. This suggests that students did not have time to discuss with their parents and teachers regarding their academic achievement. While Bertolini and Thorngren (2012) suggested that students' academic achievement can be influenced by numerous factors including their interactions with parents and teachers, the gap is likely to affect the students' academic achievement.

Table 3: Correlations between Students Achievement and Effective School Management

\begin{tabular}{llcc}
\hline & & Students' Achievement & Effective Management \\
\hline Students' & Pearson Correlation & 1 & $.315^{* *}$ \\
achievement & Sig. (2-tailed) & & .000 \\
& $\mathrm{~N}$ & 273 & 273 \\
Effective & Pearson Correlation & $.315^{* *}$ & 1 \\
Management & Sig. (2-tailed) & .000 & 273 \\
\hline
\end{tabular}

**. Correlation is significant at the 0.01 level (2-tailed).

Research Question 3: Is there significant relationship between effective school management and students' academic achievement?

As reflected in table 3 , the third question sought to establish the relationship between the dependent variable mentioned as students' perceived academic achievement and independent variable namely effective of school management. The research question called for testing of a null hypothesis which states: there is no significant relationship between effective school management and students' academic achievement. The hypothesis was tested through Pearson Correlation as observed in table 3.

The findings indicated that there is a positive significant relationship between effective school 
management and students' academic achievement ( $r=.315, N=273, p=.000$ ). It can, therefore, be concluded that effective school management slightly influenced the students' perceived academic achievements among Secondary Schools in NorthEast Tanzania.

\section{Conclusions and Recommendations}

This section provides conclusions and gives recommendations on the effect of school management on students' academic achievement.

\section{Conclusions of the Study}

Based on the findings of the study, the researchers came up with the following conclusions:

1. School management was effective in terms of planning, motivating and encouraging students to work hard toward maximized academic achievement. However, school management was perceived ineffective in terms of accepting new ideas from students and involving parents in decision making.

2. Students were satisfied with their academic achievement in annual examinations. They considered their performance in quizzes and examinations to be fair and believed that their academic competence keeps increasing from day to day. Furthermore, they were eager to continue with their academic achievement to the next level but were undecided whether teachers and parents are satisfied with their academic achievement.

3. Students' academic achievement is positively influenced be effective school management. The more the effective the school management, the better the academic achievement of students. Therefore, students' academic achievement can be enhanced through effective school management.

\section{Recommendations of the Study}

Based on the conclusions of the study, the researchers came up with the following recommendations:

1. While school management is effective in planning, motivating and encouraging students to work hard toward maximized academic achievement, the school leaders need to improve on acceptance of constructive ideas from students and involving parents in decision making processes.

2. While students were satisfied with their academic achievement, they were eager to continue with their academic achievement to the next level but were undecided whether teachers and parents are satisfied with their academic achievement, there is a need to enhance the interaction between students and their parents and teachers for them to grasp how parents and teachers perceive their academic achievement. This will help students discover their areas of weaknesses and work hard to maximize their academic achievement levels.

3. While students' academic achievement is positively influenced be effective school management, there is need for school leaders to improve their managerial practices which will enhance the level of academic achievement by students in the respective schools. .

\section{References}

Amadi E.C, (2008) Introduction to Educational

Administration; A Module. Harey Publications Port Harcourt ISBN 978 48654.

Amanchukwu, R. N., Stanley, G. J., and Ololube, N. P. (2015). A Review of Leadership Theories, Principles and Styles and Their Relevance to Educational Management. Management 5(1), 6-14.

Beck-tauber, D. (2012). Transformational Leadership: Exploring its Functionality. A dissertation submitted for the partial fulfillment of the Doctor Oeconomiae at University of St. Gallen, School of Management, Economics, Law, Social Sciences and International Affairs, Konrad, Munich.

Bertolini, K., Stremmel, A., and Thorngren, J. (2012). Student Achievement Factors. [https://www.researchgate.net/publication/ 308995147_] Site Visited on 2/2/2020.

Day, C., Gu, Q., and Sammons, P. (2016). The Impact of Leadership on Student Outcomes: How Successful School Leaders Use Transformational and Instructional Strategies to Make a Difference. 
Educational Administration Quarterly, 52(2), 221-258

Feyisa, D., Ferede, B., and Amsale, F. (2016).

Principal's perceived leadership effectiveness and its relationship with academic achievement among students in secondary school: The Ethiopian experience. Educational Research and Reviews, 11(12), 1129-1137.

Firmina, T. (2015). The impact of leadership and management on academic performance in secondary schools in Tanzania: the case of Iringa region. A dissertation submitted in partial fulfillment of the requirements for the degree of master of education in administration, planning and policy studies at Open University of Tanzania.

Igbinoba O.K \& Marvelous A.I (2015), The Impact of Classroom Management on Students' Academic Performance in Selected Junior Secondary Schools in Municipal Area Council, Abuja. International Journal of Education and Research 3(9), 141-154

Jacobson, S. (2011). Leadership effects on student achievement and sustained school success. International Journal of Educational Management, 25(1), 33-44.

Jengo, L. S. (2016). School management in community secondary schools in Rombo district: effects on the students' academic performance. A dissertation submitted in partial fulfillment of the requirements for the degree of master of education in administration, planning and policy studies at Open University of Tanzania.

Mwangi, R (2016) Impact of School Leadership on Academic Achievement in Kenyan
Secondary Schools. A Thesis submitted in partial of the fulfillment of the requirements for the Doctor of Management program at the Weatherhead School of Management.

Nzoka, J. T., and Orodho, J. A. (2014). School Management and Students' Academic Performance: How Effective are Strategies being Employed by School Managers in Secondary Schools in Embu. International Journal of Humanities and Social Science, 4(9), 86-99.

Obama, M. O., Eunice, L. A., and Orodho, J. A. (2015). Effect of Principals' Leadership Styles on Students Academic Performance in Public Secondary Schools in Homa-Bay County, Kenya. IOSR Journal Of Humanities And Social Science (IOSR-JHSS), 20(3), 5160. https://doi.org/10.9790/083720375160

Owan, V.J, Nwannumu B, Iheoma and Madukwe E, Chijioke (2018) Problem of School Management and Students Academic Performance in Secondary schools in Calabar Education Zone, Cross river State, Nigeria. International Journal of Research and Innovation in Social Science (IJRISC), 2(10), 120 - 127

Surya, P. (2011). Educational management: Handbook for School of Education Student. [http://staff.uny.ac.id/sites/default/files/pe ndidikan/Priadi Surya] Site Visited 6/8/2020

Wahlstrom K, Louis S, Leithwood K \& Anderson S (2010) how does leadership affect the student achievement Results from a national US survey. School Effectiveness and School Improvement 21(3), 315-33. 